\title{
TV and Cinema Advertising in a High Spending Retail Market- UAE
}

\author{
Sajid Marickar, D.Rajasekar
}

\begin{abstract}
Most shoppers scour the internet and shop in the brick and mortar store. Because of these factors, TV and Cinema advertisement is a very risky proposition that needs a clear understanding of the tastes of TV and Cinema Viewing for marketers to succeed in this market.
\end{abstract}

\section{Keywords : TV and Cinema, UAE retail market, Dubai Mall, Luxury brands, Retail sales, TV channels, MBC, Marketing, Advertising, Market Research}

\section{INTRODUCTION}

Dubai is the Gulf Cooperation Council (GCC) region's major tourism-cum-retail destination. In the past, these two industries (retail and tourism) have been intertwined and Dubai has been rightly considered the "shopping capital of the Middle east" (Anwar, 2004). Each year, millions of tourists visit the Emirates. The Dubai Shopping Festival (DSF), which provides tremendous discounts by three thousand retail stores and 50 malls, is also sponsored by the world-famous Dubai Shopping Festival. The UAE is packed with a cosmopolitan community from all over the world (Masad, 2008). Shopping in Dubai, according to the shoppers who prefer buying from malls, is a mixture of five variables: environment, physical infrastructure, emphasis on advertising, comfort (Prashar, 2013). Coupled with mega-projects such as The Palm, The World, the Burj Al Arab, the shopping festivals have earned Dubai a prominent place beyond industry on the global map but as a tourist hotspot (Matly, 2007).

\section{IMPORTANCE OF ADVERTISING: SPENDING AND RENTALS IN THE RETAIL SECTOR}

Consumer spending in the UAE per capita is expected to rise by $45.8 \%$ in 2017 , compared to an average regional growth of $47.2 \%$. A UAE household's average spending power is $\$ 14,400$ per year. With an average of $\$ 23,000$ per year, Emirati households make a significant contribution to this, while Asian households spend an average of $\$ 10,000$ per year (Gissing, 2008). Dubai's average retail rental rates are \$114 per sqft. per year and \$71 per sqft in Abu Dhabi per year. Companies should direct their attention from driving sales to optimizing consumer lifetime value (Roland T. Rust) in order to compete in this intensely interactive environment. Dubai has reduced its dependency on the oil industry over the past three decades. As a result, projections indicate that Dubai's economy may have relatively small impacts from lower global oil prices. The budget for 2015 revealed that oil represented

Revised Version Manuscript Received on 16 September, 2019.

Sajid Marickar, Research Scholar, AMET Business School.

Dr. D.Rajasekar, Professor, AMET Business School
$4 \%$ of the total revenues of Dubai (Deloitte, 2015) down by $5 \%$ from 2014. Retail is therefore of paramount importance for both the nation and the companies.

\section{IDEAL HIGH NET WORTH MARKET: A HIGH SPENDING RETAIL MALL PARADISE}

Dubai is home to 385 luxury stores and brands. This makes the Dubai luxury industry, the main trading hub of the GCC with luxury retail sales rising by 12 percent per year average compared to 7 percent worldwide (Luxury Movement, 2009). Although tourism is considered a major driver of growth in the retail market, growing urbanization also encourages this significant growth (Bagaeen, 2007). The retail trade turnover of Dubai in 2013 was reported at USD 39.6bn (A.T. Kearney, 2013). Mall opening hours can be extended as late as midnight during religious and public holidays. Trade hours are critical if demand and customer expectations are to be kept up (Turner and Townsend, 2014). The shopping mall model is updated to meet target market demands (Singh H. \&., 2008). Based on merchandise and labels, it is difficult for shoppers to differentiate between two malls (Sahay, 2012). Marketing strategies for the UAE market need a local modification to succeed. (Rehman, 2008). The subject of standardization and modification of advertisement messages has been debated by marketing professionals for the past 50 years. Messages that are homogeneous in nature are essential for the building of brands, but the impact of transition can not be ignored (M Kalliny, 2009). Shopping is an important distinguishing factor in such situations, since shoppers choose a mall with a comparable product, but an outstanding shopping experience (Singh H, 2012). The UAE is seen as a well-educated expert on consumer goods, including entertainment, vehicles and home products, such as cleaning products, appliances and electronics relative to other Islamic countries (Marinov, 2007).

\section{DATA COLLECTION}

The results from the data collected from 400 questionnaires are analyzed in this section. It also highlights the results obtained from the primary data collected to analyze the multichannel shopping environment in the United Arab Emirates. It's a sampling of non-probability which includes the sample being taken from a portion of the population. Sample population is chosen because it is readily and easily accessible and also very convenient. The researcher who uses such a sample cannot scientifically generalize the total population from this sample because it is not adequately representative. A random sample is taken from each stratum relative to the size of the stratum in relation to the population. 


\section{RESEARCH METHODOLOGY}

This study was conducted with the primary goal of determining the attitudes of consumers towards TV and categories of cinema ads. A standardized questionnaire for the collection of data has been developed and used as a primary survey method. The study questionnaire addresses the issue of data quality by reducing or removing variations in how questions are being asked and how they are being answered to the participants. A survey was developed and pilot analyzed in the retail environment in Dubai through personal interviews with five senior professionals.

\section{MAJOR TV CHANNELS IN THE UAE}

\begin{tabular}{|c|c|c|c|c|c|}
\hline Rank & Channels & TRP & Share & $\begin{array}{l}\text { Rating } \\
\%\end{array}$ & Reach\% \\
\hline 1 & $\overline{M B C 2}$ & 529.3 & 3.97 & 1.1 & 88 \\
\hline 2 & MBC 1 & 382.8 & 2.87 & 0.8 & 80 \\
\hline 3 & Cartoon Network Arabic & 218.5 & 1.64 & 0.46 & 57 \\
\hline 4 & MBC Bollywood & 205.4 & 1.54 & 0.43 & 81.8 \\
\hline 5 & MBC Max & 197.8 & 1.48 & 0.41 & 84.6 \\
\hline 6 & Asianet Middle East & 184.5 & 1.38 & 0.38 & 65.9 \\
\hline 7 & MBC 3 & 182.2 & 1.37 & 0.38 & 73.6 \\
\hline 8 & Baraem & 158.8 & 1.19 & 0.33 & 64.5 \\
\hline 9 & Asianet News & 156.4 & 1.17 & 0.33 & 66.2 \\
\hline 10 & MBC 4 & 154.1 & 1.16 & 0.32 & 83.5 \\
\hline 11 & MBC Action & 145.9 & 1.09 & 0.3 & 82.5 \\
\hline 12 & MBC Drama & 133.9 & 1 & 0.28 & 80.8 \\
\hline 13 & Fox Movies & 125.6 & 0.94 & 0.26 & 78.2 \\
\hline 14 & Al Jazeera & 103 & 0.77 & 0.21 & 61.2 \\
\hline 15 & Star Plus & 86.1 & 0.65 & 0.18 & 43.7 \\
\hline 16 & Colors & 84.8 & 0.64 & 0.18 & 39.1 \\
\hline 17 & Dubai Al Oula & 81.9 & 0.61 & 0.17 & 73.6 \\
\hline 18 & Mazhavil Manorama & 74.7 & 0.56 & 0.16 & 67.2 \\
\hline 19 & $\begin{array}{l}\text { National Geographic Abu } \\
\text { Dhabi }\end{array}$ & 73.8 & 0.55 & 0.15 & 74 \\
\hline 20 & Zee Aflam & 71.5 & 0.54 & 0.15 & 80 \\
\hline
\end{tabular}

(Fig. 1)

The above table (Fig.1) illustrates the reach, rating and market share of the major channels in the Television industry of UAE. The channel with the highest TRP is MBC 2. It occupies a market share of $3.97 \%$ having a reach of $88 \%$. The channel has the highest rating and is seen by the majority of UAE population as it showcases 24-hours western movies. Just after that comes MBC 1 both being a part of MBC group (Middle East Broadcasting Center) is one of the largest media company in the Middle East and North Africa region. MBC 1 has a reach of $80 \%$ and offers family entertainment shows. The other channels of MBC group, MBC Bollywood and MBC Max are at a position of 4 and 5 with a reach of $81.8 \%$ and $84.6 \%$ respectively. MBC 3 and MBC 4 are at 7 th and 10th position respectively with a better reach than most of their competitors. The third position is acquired by Cartoon
Network Arabic with a TRP rate of 218.5 and reach of $57 \%$. The channel having a better reach yet the lowest TRP is Zee Alfam.

\section{TELEVISION MEDIA METRICS}

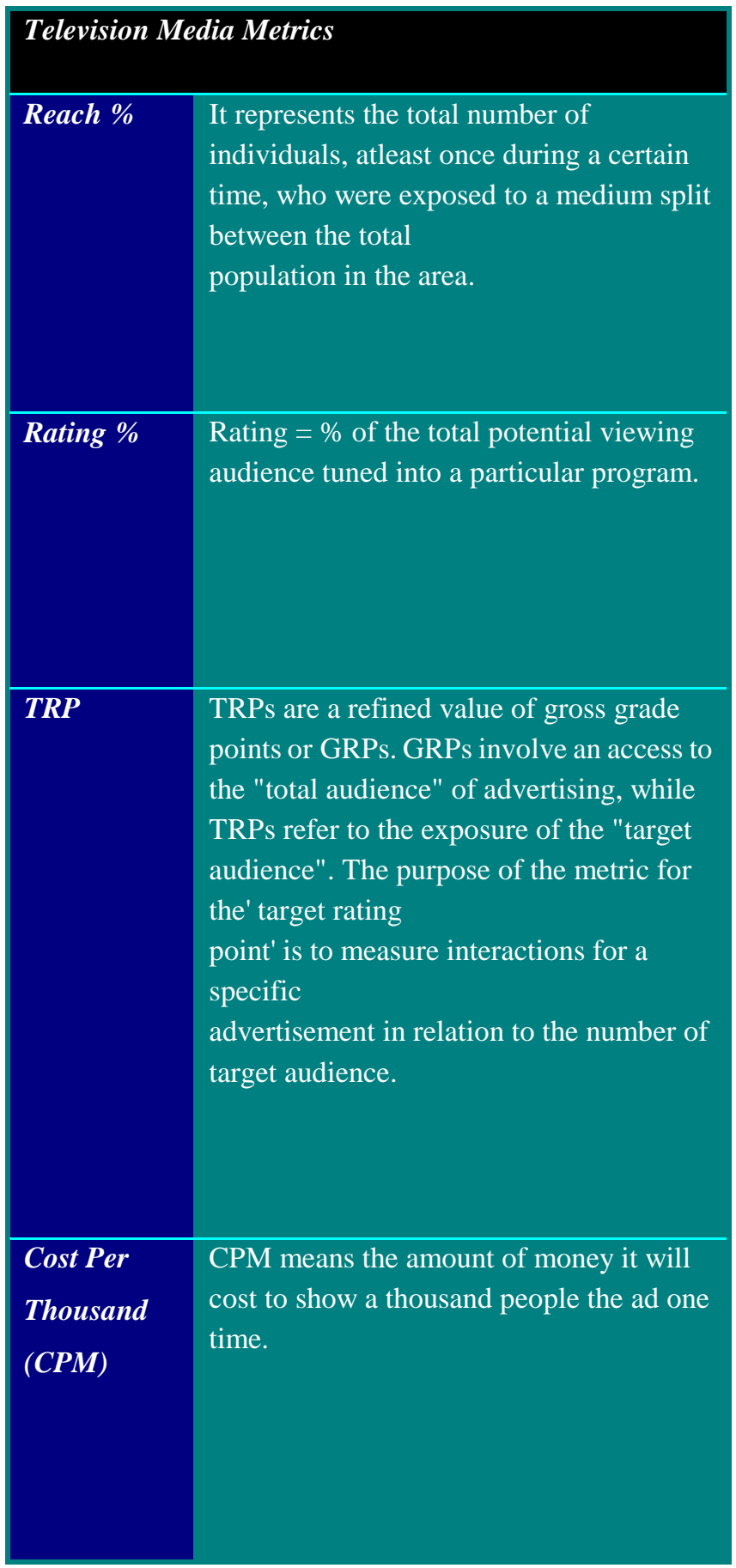

(Fig.2)

The table (Fig.2) defines the metrics that determine the market value of any Television content. These metrics are evaluated to understand the success of any show/media content.

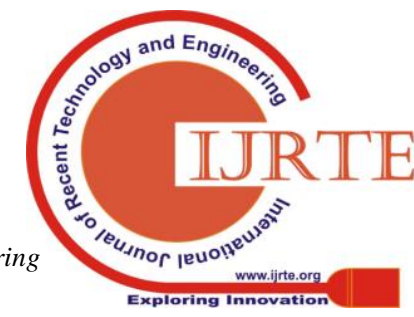




\section{FINDINGS FROM THE SURVEY}

\begin{tabular}{|c|c|c|c|c|c|c|c|c|c|c|c|c|c|}
\hline \multirow{3}{*}{ Variable } & \multirow{3}{*}{ Group } & \multicolumn{10}{|c|}{ Online Vs. Offline time Usage [TV-Satillite (eg.OSN] } & \multirow{3}{*}{ Total } & \multirow{3}{*}{$\mathbf{P}$} \\
\hline & & \multicolumn{2}{|c|}{$\begin{array}{l}\text { Daily(more } \\
\text { than } 30\end{array}$} & \multicolumn{2}{|c|}{\begin{tabular}{|l|} 
Daily-Less \\
than 30
\end{tabular}} & \multicolumn{2}{|c|}{$\begin{array}{l}2-3 \text { times a } \\
\text { week }\end{array}$} & \multicolumn{2}{|c|}{ Once A week } & \multicolumn{2}{|c|}{ Never } & & \\
\hline & & No. & $\%$ & No. & $\%$ & No. & $\%$ & No. & $\%$ & No. & $\%$ & & \\
\hline \multirow{4}{*}{ Marital Status } & Single & 34 & $51.50 \%$ & 29 & $51.80 \%$ & 54 & $66.70 \%$ & 22 & $56.40 \%$ & 107 & $67.30 \%$ & 246 & \multirow{4}{*}{$<0.330$} \\
\hline & Married & 17 & $25.80 \%$ & 15 & $26.80 \%$ & 15 & $18.50 \%$ & 8 & $20.50 \%$ & 26 & $16.40 \%$ & 81 & \\
\hline & Separated & 15 & $22.70 \%$ & 12 & $21.40 \%$ & 12 & $14.80 \%$ & 9 & $23.10 \%$ & 26 & $16.40 \%$ & 74 & \\
\hline & Total & 66 & $100.00 \%$ & 56 & $100.00 \%$ & 81 & $100.00 \%$ & 39 & $100.00 \%$ & 159 & $100.00 \%$ & 401 & \\
\hline \multirow{7}{*}{ Nationality } & Asians & 40 & $60.60 \%$ & 29 & $51.80 \%$ & 21 & $25.90 \%$ & 23 & $59.00 \%$ & 56 & $35.20 \%$ & 169 & \multirow{7}{*}{$<0.000$} \\
\hline & Arab & 10 & $15.20 \%$ & 7 & $12.50 \%$ & 8 & $9.90 \%$ & 6 & $15.40 \%$ & 27 & $17.00 \%$ & 58 & \\
\hline & European & 9 & $13.60 \%$ & 14 & $25.00 \%$ & 12 & $14.80 \%$ & 4 & $10.30 \%$ & 47 & $29.60 \%$ & 86 & \\
\hline & American & 1 & $1.50 \%$ & 1 & $1.80 \%$ & 28 & $34.60 \%$ & 3 & $7.70 \%$ & 4 & $2.50 \%$ & 37 & \\
\hline & Russian & 0 & $0.00 \%$ & 2 & $3.60 \%$ & 6 & $7.40 \%$ & 0 & $0.00 \%$ & 4 & $2.50 \%$ & 12 & \\
\hline & Others & 6 & $9.10 \%$ & 3 & $5.40 \%$ & 6 & $7.40 \%$ & 3 & $7.70 \%$ & 21 & $13.20 \%$ & 39 & \\
\hline & Total & 66 & $100.00 \%$ & 56 & $100.00 \%$ & 81 & $100.00 \%$ & 39 & $100.00 \%$ & 159 & $100.00 \%$ & 401 & \\
\hline
\end{tabular}

(Fig.3)

The above survey (Fig.3) result is based on the viewership of Satellite TV in UAE grouped in two different segments that is Marital Status and Nationality. The study involving single individuals shows that more than $51.80 \%$ watch content for less than 30 minutes in a day while $51.50 \%$ are viewing it for more than 30 minutes.

There are viewers who spend time watching satellite TV content only 2 to 3 times in a week that accounts for $66.70 \%$ while some watch it only once in a week constituting to $56.40 \%$.

The UAE TV market also has people not watching any content at all and it is $67.30 \%$, which is a big number.

Married and separated viewers are associated with satellite

and $22.70 \%$ watching content daily more than 30 minutes where Asians are the most active users with $60.60 \%$ watching TV for more than 30 minutes in a day while Russians are the least active with only $7.40 \%$ watching TV 2-3 times in a week. Europeans are comparatively more active than its other counterparts with a viewership of $25 \%$ watching TV daily less than 30 minutes.

Can enable a maker to effectively subcontract parts of work, for example as when Austin subcontracted the aluminum body work of the Austin A40 Sports to Jensen Motors.

Can permit more torsional flexing before yielding (trucks, truck-base SUVs going 4x4 romping)

TV content consumption to a very less extent with $25.80 \%$

\begin{tabular}{|c|c|c|c|c|c|c|c|c|c|c|c|c|c|}
\hline \multirow{3}{*}{ Variable } & \multirow{3}{*}{ Group } & \multicolumn{10}{|c|}{ Online Vs. Offline time Usage [TV-Satillite (eg.OSN] } & \multirow{3}{*}{ Total } & \multirow{3}{*}{$\mathbf{P}$} \\
\hline & & \multicolumn{2}{|c|}{$\begin{array}{l}\text { Daily(more } \\
\text { than } 30\end{array}$} & \multicolumn{2}{|c|}{$\begin{array}{l}\text { Daily-Less } \\
\text { than } 30\end{array}$} & \multicolumn{2}{|c|}{\begin{tabular}{|l|}
$2-3$ times a \\
week
\end{tabular}} & \multicolumn{2}{|c|}{ Once A week } & \multicolumn{2}{|c|}{ Never } & & \\
\hline & & No. & $\%$ & No. & $\%$ & No. & $\%$ & No. & $\%$ & No. & $\%$ & & \\
\hline \multirow{3}{*}{ Millennial } & Millennial & 30 & $45.50 \%$ & 34 & $60.70 \%$ & 47 & $58.00 \%$ & 21 & $53.80 \%$ & 87 & $54.70 \%$ & 219 & \multirow{3}{*}{$<0.483$} \\
\hline & Non- Millennial & 36 & $54.50 \%$ & 22 & $39.30 \%$ & 34 & $42.00 \%$ & 18 & $46.20 \%$ & 72 & $45.30 \%$ & 182 & \\
\hline & Total & 66 & $100.00 \%$ & 56 & $100.00 \%$ & 81 & $100.00 \%$ & 39 & $100.00 \%$ & 159 & $100.00 \%$ & 401 & \\
\hline \multirow{7}{*}{$\begin{array}{l}\text { Monthly } \\
\text { Income }\end{array}$} & Student/Dependent & 9 & $14.10 \%$ & 3 & $5.60 \%$ & 0 & $0.00 \%$ & 2 & $5.40 \%$ & 6 & $3.90 \%$ & 20 & \multirow{7}{*}{$<0.000$} \\
\hline & Less than AED 6000 & 5 & $7.80 \%$ & 3 & $5.60 \%$ & 7 & $8.90 \%$ & 5 & $13.50 \%$ & 24 & $15.50 \%$ & 44 & \\
\hline & AED 6000- AED 12000 & 12 & $18.80 \%$ & 18 & $33.30 \%$ & 15 & $19.00 \%$ & 8 & $21.60 \%$ & 38 & $24.50 \%$ & 91 & \\
\hline & AED 12000-AED 18000 & 21 & $32.80 \%$ & 18 & $33.30 \%$ & 12 & $15.20 \%$ & 9 & $24.30 \%$ & 38 & $24.50 \%$ & 98 & \\
\hline & AED 18000-AED24000 & 10 & $15.60 \%$ & 4 & $7.40 \%$ & 4 & $5.10 \%$ & 5 & $13.50 \%$ & 12 & $7.70 \%$ & 35 & \\
\hline & More than AED 24000 & 7 & $10.90 \%$ & 8 & $14.80 \%$ & 41 & $51.90 \%$ & 8 & $21.60 \%$ & 37 & $23.90 \%$ & 101 & \\
\hline & Total & 64 & $100.00 \%$ & 54 & $100.00 \%$ & 79 & $100.00 \%$ & 37 & $100.00 \%$ & 155 & $100.00 \%$ & 389 & \\
\hline
\end{tabular}

(Fig.4)

The given survey (Fig.4) is based on the consumption of Satellite TV content by different age and income categories. Millennial consisting of individuals within the age group of 22-37 has the highest consumption of satellite TV at $45.50 \%$ spending more than 30 minutes and $60.70 \%$ spending less than 30 minutes on a daily basis. The non-millennial that is the older generation has comparatively lesser consumption at $54.50 \%$ watching content for more than 30 minutes and $39.30 \%$ spending less than 30 minutes of their time daily. The rate of consumption also varies largely among individuals of different income groups. Students or individuals who are dependent on their family do not spend much time watching satellite TV content. It is at $14.10 \%$ for daily consumption of more than 30 minutes. The study reveals that more the income, more is the overall consumption of satellite TV content. $51.90 \%$ of individuals with an income of more than AED 24000 consume content 2 to 3 times a week that is the highest among any other income group. Other income groups have similar consumption rate that do not differ to a large extent except the middle and lower income groups that is less than AED 6000 and between AED 6000 to AED 18000. 


\begin{tabular}{|c|c|c|c|c|c|c|c|c|c|c|c|c|c|}
\hline \multirow{3}{*}{ Variable } & \multirow{3}{*}{ Group } & \multicolumn{10}{|c|}{ Online Vs. Offline time Usage [TV-Satillite (eg.OSN] } & \multirow{3}{*}{ Total } & \multirow{3}{*}{$\mathbf{P}$} \\
\hline & & \multicolumn{2}{|c|}{\begin{tabular}{|l|}
$\begin{array}{l}\text { Daily(more } \\
\text { than } 30\end{array}$ \\
\end{tabular}} & \multicolumn{2}{|c|}{\begin{tabular}{|l} 
Daily-Less \\
than 30
\end{tabular}} & \multicolumn{2}{|c|}{$\begin{array}{l}2-3 \text { times a } \\
\text { week }\end{array}$} & \multicolumn{2}{|c|}{ Once A week } & \multicolumn{2}{|c|}{ Never } & & \\
\hline & & No. & $\%$ & No. & $\%$ & No. & $\%$ & No. & $\%$ & No. & $\%$ & & \\
\hline \multirow{5}{*}{ Career Level } & Entry Level & 3 & $4.60 \%$ & 1 & $1.90 \%$ & 2 & $2.60 \%$ & 2 & $5.30 \%$ & 21 & $13.50 \%$ & 29 & \multirow{5}{*}{$<0.001$} \\
\hline & Mid-Career & 32 & $49.20 \%$ & 26 & $49.10 \%$ & 24 & $30.80 \%$ & 16 & $42.10 \%$ & 69 & $44.20 \%$ & 167 & \\
\hline & Management & 22 & $33.80 \%$ & 20 & $37.70 \%$ & 49 & $62.80 \%$ & 15 & $39.50 \%$ & 54 & $34.60 \%$ & 160 & \\
\hline & Unspecified & 8 & $12.30 \%$ & 6 & $11.30 \%$ & 3 & $3.80 \%$ & 5 & $13.20 \%$ & 12 & $7.70 \%$ & 34 & \\
\hline & Total & 65 & $100.00 \%$ & 53 & $100.00 \%$ & 78 & $100.00 \%$ & 38 & $100.00 \%$ & 156 & $100.00 \%$ & 390 & \\
\hline \multirow{4}{*}{$\begin{array}{l}\text { Education } \\
\text { level }\end{array}$} & Undergraduate & 18 & $27.30 \%$ & 10 & $17.90 \%$ & 3 & $3.70 \%$ & 4 & $10.30 \%$ & 27 & $17.00 \%$ & 62 & \multirow{4}{*}{$<0.014$} \\
\hline & Graduate & 27 & $40.90 \%$ & 19 & $33.90 \%$ & 40 & $49.40 \%$ & 16 & $41.00 \%$ & 65 & $40.90 \%$ & 167 & \\
\hline & Post-Graduate & 21 & $31.80 \%$ & 27 & $48.20 \%$ & 38 & $46.90 \%$ & 19 & $48.70 \%$ & 67 & $42.10 \%$ & 172 & \\
\hline & Total & 66 & $100.00 \%$ & 56 & $100.00 \%$ & 81 & $100.00 \%$ & 39 & $100.00 \%$ & 159 & $100.00 \%$ & 401 & \\
\hline
\end{tabular}

(Fig.5) The above graph (Fig.6) depicts the percentage of viewers as

The Satellite TV market or viewership can also be distinguished by factors like Career Level and Education Level. Individuals at the entry level of their career watching content for more than 30 minutes accounts to $4.60 \%$ and $1.90 \%$ of them invest less than 30 minutes while $13.50 \%$ of them have never watched any content. Individuals at the mid-level of their career have the highest consumption at $49.20 \%$ of them watching content for more than 30 minutes daily. Individuals at the manager level often watch content only 2 to 3 times in a week, which constitutes to $62.80 \%$.

The Satellite TV content has been diverse and has been in a constant evolutionary stage. This signifies the important of segregating consumers also based on education.

Undergraduates have comparatively lesser consumption. $27.30 \%$ of them spend more than 30 minutes daily while $17 \%$ of them have never watched any. Graduates and Post-graduates have a similar rate of consumption with $40.90 \%$ and $31.80 \%$ of them respectively, watching content for more than 30 minutes daily while $46.40 \%$ of graduates and $46.90 \%$ of post-graduates watching content 2 to 3 times in a week.

\section{CINEMA ADVERTISING}

Cinema advertising's distinct advantage is that the audience is exclusive, regional and fully screen-focused. Cinema advertisement, driven largely by the number of screens present, represents a minor fraction of total marketing spending despite the region's low number of per capita cinema screens. The number of screens in the UAE, with a population of around 5 million, has reached more than 500. According to the statistics cited by cinema advertiser Motivate Val Morgan, the amount of money spent on cinemas across the UAE in the first half of 2014 was $31 \%$ higher than in the same timeframe last year.

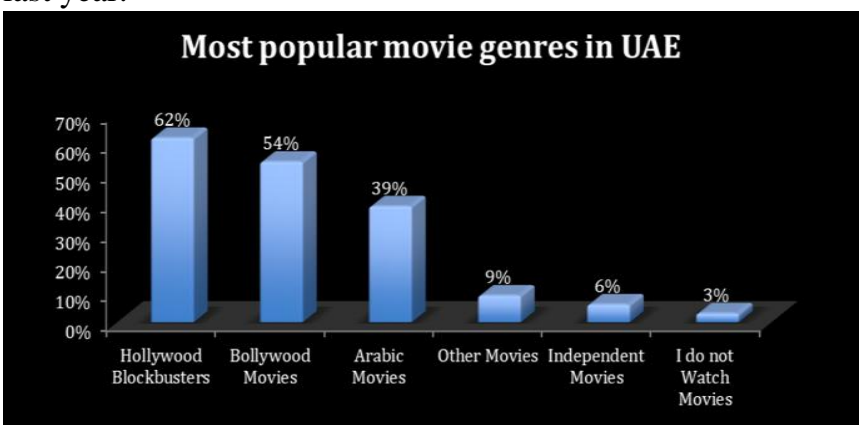

(Fig.6) per various movie genres, famous in UAE. Hollywood Blockbusters has the highest number of audience followed by Bollywood movies at 54\%. $3 \%$ of the participants do not watch movies at all.

\section{GAPS AND LIMITATIONS IN CURRENT STUDY}

Customers view products on one network however, they buy them on another channel and track their orders on another channel. It makes it very difficult to estimate a specific channel's ROI(Return on Investment). The principle is about 'round the clock purchase'. This channel change can help retailers reduce overhead operations and experience customer satisfaction when used appropriately (Retail Systems Research, 2011). Many shoppers do their research on the Internet and make purchases in the bricks-and-mortar store (Neslin G. L., 2006). These reasons are making the TV and Cinema advertising a very risky proposition and hence a clear understanding of the TV and Cinema Viewing preferences are required for brands to be successful in this segment.

\section{REFERENCES}

1. A.T. Kearney. (2013). Dubai Retail Snapshot. A.T. Kearney.

2. Anwar, S. \&. (2004). Festival Tourism in the United Arab Emirates: First-time Versus Repeat Visitor Perceptions. Journal of Vacation Marketing, 10 (2): 161-170.

3. Bagaeen, S. (2007). Brand Dubai: The Instant City; or the Instantly Recognizable City. International Planning Studies, 12 (2): 173-197.

4. Deloitte. (2015). Middle East Real Estate Predictions: Dubai . Dubai: Deloitte.

5. Gissing, S. \&. (2008). Dubai Retail Snapshots. Dubai: Colliers International.

6. Luxury Movement. (2009). Luxury Retail Market Overview. Dubai: Luxury Movement.

7. M Kalliny, S. G. (2009). The Role of the Advertising Agency in the Cultural Message Content of Advertisements: A Comparison of the Middle East and the United States.

8. Marinov, M. (2007). Marketing in the emerging markets of Islamic countries. . New York: Palgrave MacMillan.

9. Masad, M. (2008, Autumn). Dubai: What cosmopolitan city . ISIM Review, pp. 10-11.

10. Matly, M. (2007). DUBAI STRATEGY: PAST, PRESENT, FUTURE Harvard Business School.

11. Neslin, G. L. (2006). Challenges and Opportunities in Multichannel Management. Journal of Service Research, 95-113.

12. Prashar, S. (2013). Factors Defining Shopping Experience: An Analytical Study. Asian Journal of Business Research, 36.

13. Rehman, A. (2008). Dubai \& Co.: Global strategies for doing business in the Gulf States. New York: McGraw-Hill. 
14. Retail Systems Research. (2011). Future of Retail Benchmark Report.

15. Roland T. Rust, C. M. (n.d.). Rethinking Marketing. 2015: Harvard Business Review.

16. Sahay. (2012). Determinants of Shopping Experience. International Journal of Retail and Distribution Management, 235-248.

17. Singh H, V. S. (2012). Determinants of Shopping Experience:: Exploring the Mall. International Journal of Retail and Distribution Management, 40 (3): 235-248.

18. Singh, H. \&. (2008). My American Cousin: A Comparison between Indian and the US Shopping Malls. . Journal of Asia-Pacific Business, 9(4).

19. Turner \& Townsend. (2014). Global retail market insight. Dubai: Turner \& Townsend 